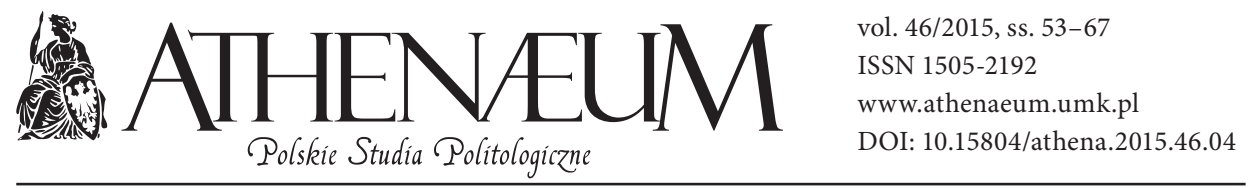

\title{
MUZUŁMANIE WE FRANCJI - ASPEKTY RELIGIJNE I ORGANIZACYJNE
}

\author{
Stanisław Musiał*
}

\author{
MUSLIMS IN FRANCE IN TERMS OF RELIGIOUS AND \\ ORGANIZATIONAL BACKGROUNDS
}

\begin{abstract}
At the turn of the twentieth and twenty-first century, the problem of the Muslim minority in Europe became a significant problem in religious, social and political terms. In this publication, we present the characteristics of the presence of Muslims in France only in terms of religious and organizational backgrounds. By analyzing the first aspect, the importance of Islam as the second religion in terms of the number of believers in France is shown. The second aspect describes the characteristics of some important Muslim organizations in France.
\end{abstract}

_ KEYWORDS

France, Muslims, religion, organizations, believers

Temat mniejszości muzułmańskiej we Francji jest istotny zarówno z punktu widzenia poznawczego, jak też z punktu widzenia praktyki politycznej. Jako przedmiotu poznania nabiera szczególnej wagi w dzisiejszych czasach mieszania się narodów i kultur. Obserwowanie tych procesów we Francji ma dodatkowy walor heurystyczny, gdyż kraj ten - z racji mieszania się nie tylko kultur różnych, ale często przeciwstawianych sobie - stanowić może niejako laboratorium doświadczania tychże procesów, ale już w wymiarze światowym. Natomiast

* Akademia Marynarki Wojennej w Gdyni, Instytut Stosunków Międzynarodowych. 
wartość praktyczna badania tej problematyki polega na zdiagnozowaniu zagrożeń i szans tkwiących w tych procesach, a przez to kierowania nimi w sposób racjonalny.

Już na początku procesu badawczego spotykamy się z podstawową przeszkodą, a mianowicie $\mathrm{z}$ trudnością zdefiniowania samego przedmiotu poznania. Spotkaliśmy się z traktowaniem pojęć „muzułmanie we Francji”, czy też niekiedy „muzułmanie francuscy”, bardzo restrykcyjnie, to znaczy ograniczeniem tej grupy tylko do osób jasno deklarujących się jako muzułmanie i praktykujących tę religię. Z drugiej strony pojęcie to odnoszone jest do szerokiego spektrum osób - od wymienionych przed chwilą, poprzez wierzących, ale nie praktykujących, aż po osoby luźno związane $z$ tą religią, czy to przez pochodzenie etniczne, czy też wychowanie w kulturze islamskiej. To drugie stanowisko jest nam bliższe. Stąd też pojęcie „muzułmanie we Francji” obejmować będzie osoby urodzone w kraju, w którym wiara ta jest dominująca, oraz ich bezpośrednich potomków, a także osoby deklarujące tę wiarę, lecz nie spełniające poprzednich warunków (konwertyci)ํㅗ․

\section{MIEJSCE ISLAMU JAKO RELIGII WE FRANCJI}

Francja jest postrzegana jako „najstarsza córa Kościoła”. Jednak ostatnie kilkadziesiąt lat to proces jej dechrystianizacji. Jeszcze w 1905 roku katolicy stanowili około 90\% ludności Francji, w 1986 roku - 81\%, w 2006 roku - 65\%, zaś w 2011 roku już tylko $61 \%{ }^{2}$. Ten znaczący spadek jest bardzo wyraźny w grupie wiekowej do 35 lat, co prowadzi analityków z CSA do wniosku, iż bezwyznaniowcy (obecnie 25\% według sondażu IFOP z 2011 roku i 32\% według sondażu CSA z 2012 roku) będą grupą dominującą w społeczeństwie francuskim³ ${ }^{3}$.

${ }^{1} \mathrm{Na}$ gruncie francuskim klasyfikację taką stosuje np. szeroko znany Francuski Instytut Opinii Publicznej (Institut Français d'Opinion Publique), najstarsza, założona w 1938 roku, „sondażownia” francuska. W publikacji tej szeroko korzystamy z wyników badań tego Instytutu, szczególnie z pracy: IFOP, Analyse: 1989-2011.Enquête sur l'implantation et l'évolution de l'islam de France, Juillet 2011, http://www.ifop.com/media/pressdocument/343-1-file.pdf, odczyt z dn. 10.10.2012. W Polsce podobna klasyfikacja zastosowana jest w: K. Pędziwiatr, Od islamu imigrantów do islamu obywateli: muzułmanie w krajach Europy Zachodniej, Kraków 2007, s. 43-44; K. Gajlewicz-Korab, Obraz muzułmanów we Francji w tamtejszych tygodnikach opinii, Warszawa 2011, s. 29-30.

${ }^{2}$ Według sondażu CSA z 2012 roku katolicyzm wyznawało 56\% Francuzów. Zob. Y.M. Cann, CSA décrypte... Le catholicisme en France, s. 3, http://www.csa.eu/multimedia/date/etudes/etu20130329note-d-analyse-csa-decrypte-mars-2013.pdf, odczyt z dn. 10.7.2013.

${ }^{3}$ Ibidem. 
Tab. 1. Przynależność religijna Francuzów w 2011 roku (wartości procentowe)

\begin{tabular}{|l|c|}
\hline Ogółem katolicy & 61 \\
\hline \multicolumn{1}{|c|}{ praktykujący } & 15 \\
niepraktykujący & 46 \\
\hline Protestanci & 4 \\
\hline Muzułmanie & 7 \\
\hline Żydzi & 1 \\
\hline Inna religia & 2 \\
\hline Bezwyznaniowcy & 25 \\
\hline Brak odpowiedzi & 0 \\
\hline Ogółem & 100 \\
\hline
\end{tabular}

Źródło: IFOP, Les Français et la croyance religieuse. Résultats detaillés, avril 2011, s. 7, http://www.ifop.com/?option=com_publication\&type $=$ poll\&id=1479, odczyt $\mathrm{z}$ dn. 13.04.2013.
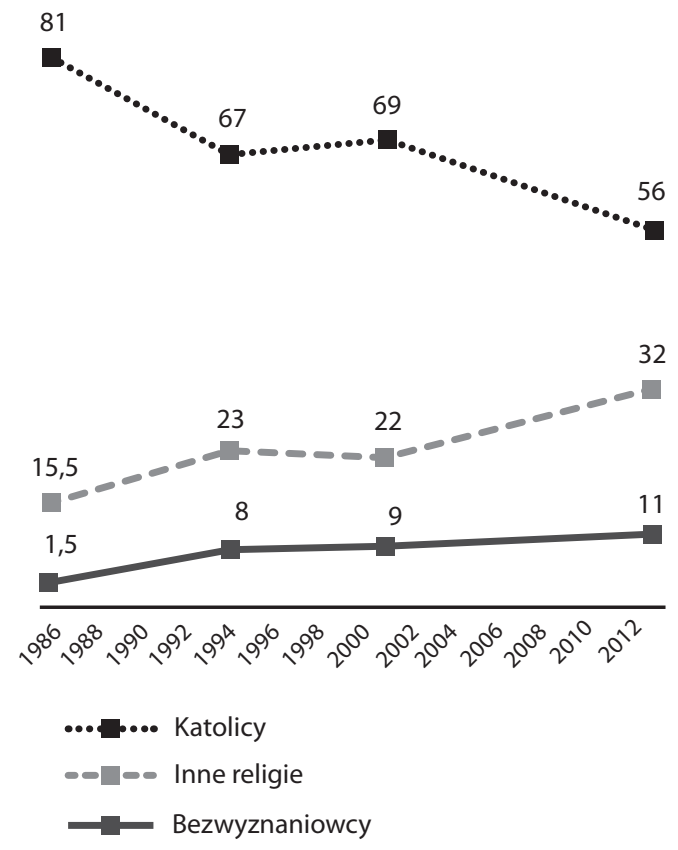

Wykres 1: Ewolucja liczby wyznawców głównych religii we Francji w latach 1986-2012 w procentach

Źródło: Y.M. Cann, CSA décrypte..., op.cit., s. 1. 
Wprost przeciwna tendencja występuje w grupie wyznawców islamu, którzy jeszcze w 1982 roku stanowili 2,5\% społeczeństwa francuskiego, a w 2011 roku już 7\%, stając się drugą religią w państwie. Jest to niejako trend światowy, gdyż jak triumfalnie podano na portalu muzułmańskim - islam z liczbą 1322 tys. wiernych (19\% populacji świata) stał się pierwszą liczebnie religią światową przed katolicyzmem $(17,5 \%)^{4}$. Liczby te są wiarygodne, co przyznał Watykan, lecz nie ujmują chrześcijaństwa jako całości, czyli 2 mld wiernych5

Ulega wzmocnieniu także religijność muzułmanów: $25 \% \mathrm{z}$ nich uczęszcza w każdy piątek do meczetu, gdy w 2001 roku chodziło tam 20\% , a 16\% w 1989 roku.

\section{a. Miejsca kultu religijnego}

Istotnym aspektem funkcjonowania społeczności muzułmańskiej we Francji są możliwości, które stwarza państwo dla kultywowania religii. Temat jest żywo komentowany we Francji w związku z podnoszeniem przez społeczność muzułmańską problemu zbyt małej ilości miejsc kultu swej religii.

W 2010 roku istniało we Francji według ministerstwa spraw wewnętrznych 2368 takich miejsc, w tym 2052 w metropolii ${ }^{6}$. Dla porównania miejsc kultu katolickiego jest 45 000, protestanckiego - 3000, a żydowskiego - 280. Trzeba podkreślić ogromną dynamikę wzrostu liczby muzułmańskich miejsc kultu. W 1970 roku było ich tylko 100, w 1985 - 500, w 2000 - 1803. Zjawisko to związane jest z decyzją imigrantów dotyczącą pozostania na stałe we Francji, a także rodzeniem się klasy średniej wśród ludności muzułmańskiej, i co z tym się łączy - większymi jej możliwościami finansowania budowy tych miejsc, gdyż finansowanie zewnętrzne gra rolę marginalną7. Oczywiście nie wszystkie z nich to „wielkie meczety” z minaretami i wyróżniającą je architekturą (jest ich tylko

${ }^{4}$ L'islam est officiellemnt reconnu comme la première religion du monde, http://oumma..com/18477/ lislam-officiellement-reconnu-premiere-religion-monde, odczyt z dn. 10.05.2013.

5 Ibidem.

6 Zob. Les lieux de culte musulmans ont double en vingt ans, http://www.lefigaro.fr/actualitefrance/2011/08/30/01016-20110830ARTFIG00587-les-lieux-de-culte-musulmans-ont-double-envingt-ans.php, odczyt z dn. 11.05.2013 ; Qui a dit qu'il n'y avait pas assez de mosquées en France?, http://www.atlantico.fr/decryptage/mosquees-france-augmentation-constante-preuve-integrationislam-172908.html, odczyt z dn. 01.02.2012. Zob także: G. Couvreur, Musulmans de France. Diversité, mutations et perspectives de l'islam français, Les Éditions de l'atelier, Paris 1998, s. 51-55.

${ }^{7}$ Ibidem. 
50); ogromna większość to przysposobione na ten cel pawilony i sale modlitwy ${ }^{8}$. Pomimo iż liczba miejsc kultu w ciągu 20 lat podwoiła się, to środowiska muzułmańskie uważają, iż winna zwiększyć się co najmniej jeszcze o połowę ${ }^{9}$.

\section{b. Praktykowanie życia religijnego}

Wspomniany wcześniej podział francuskich muzułmanów na trzy grupy, tzn. wierzących i praktykujących, wierzących niepraktykujących oraz pochodzenia muzułmańskiego, ma swoje uzasadnienie statystyczne. Liczebność tych grup wynikająca z sondaży w 2011 roku jest następująca: pierwsza grupa - 41\%, druga - $34 \%$, trzecia $22 \%$, zaś odniesienie ich do odpowiednich grup katolickich jest widoczne $\mathrm{w}$ poniższym zestawieniu.

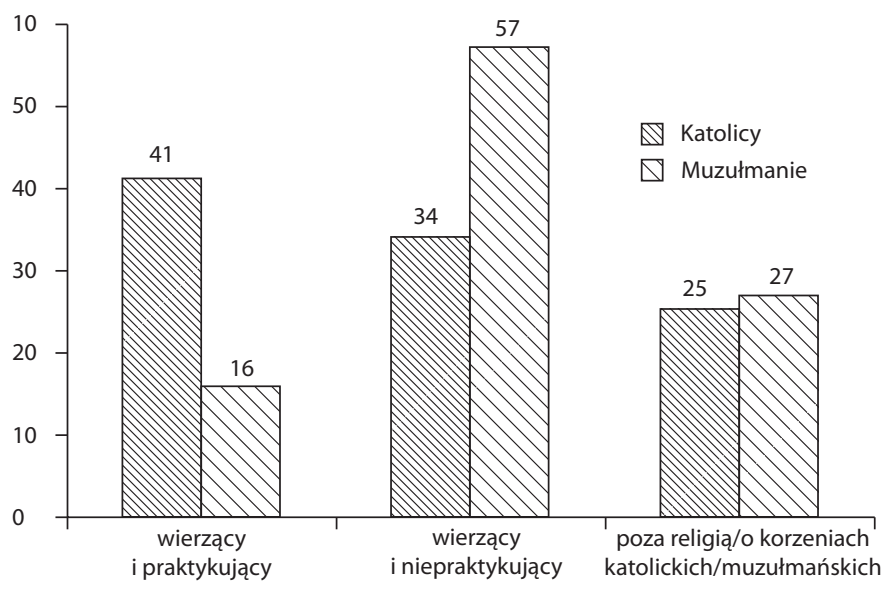

Wykres 2: Stosunek do religii muzułmanów i katolików

Źródło: IFOP, Analyse: 1989-2011..., op.cit., s. 7.

Powyższy wykres wskazuje na większe przywiązanie francuskich muzułmanów do swej wiary, niż jest to w przypadku katolików. Szczególnie jest to zauważalne w grupie wierzących i praktykujących.

\footnotetext{
8 Ibidem.

${ }^{9}$ Les lieux de culte musulmans ont doublé..., op.cit.
} 


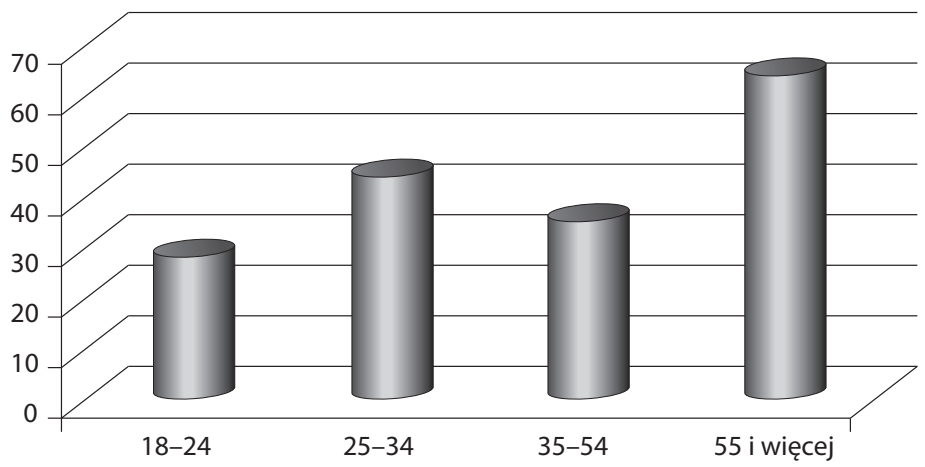

Wykres 3: Codzienna modlitwa w grupach wiekowych wśród muzułmanów Źródło: IFOP, Analyse: 1989-2011..., op.cit. s. 9.

Podobna tendencja występuje w odniesieniu do gorliwości wyznawanej wiary, mierzonej codzienną modlitwą i uczęszczaniem do miejsc kultu co najmniej raz w tygodniu (muzułmanie w piątek, katolicy raz w tygodniu). $\mathrm{W}$ ten ostatni sposób praktykuje wiarę 25\% muzułmanów (patrz wykres 4) (katolików 12\% ${ }^{10}$ ), gdy jeszcze w 2001 roku było ich 20\%, a w 1989 roku tylko 16\%.

Najbardziej znaczący wzrost gorliwości religijnej zanotowano w najmłodszej grupie wiekowej: poniżej 25 lat, w której przyrost wyniósł od 7\% w 1989 roku do $23 \%$ obecnie. Także w innych sferach muzułmanie wykazują dużą pobożność. I tak podczas ramadanu postu przestrzega $71 \%$ wiernych, $49 \%$ kupuje więcej niż poprzednio produktów halal, a dwie trzecie systematycznie sprawdza skład kupowanych towarów pod kątem, czy nie zawierają składników niezgodnych $\mathrm{z}$ halal ${ }^{11}$.

Od połowy lat osiemdziesiątych obserwujemy narodziny zjawiska, które nazwać możemy „nową religijnością islamską”. Rozpowszechnia się ona szczególnie wśród młodzieży pochodzenia maghrebińskiego - urodzonej już we Francji - i odbiega od tradycyjnego pojmowania religijności ich rodziców. Często określa się tę postawę „neokomunitaryzmem”. Polega ona na odwoływaniu się do nowych więzi - przede wszystkim etnicznych, regionalnych czy lokalnych - i szukaniu na tych właśnie szczeblach możliwości działań, takich jak: tworzenie sieci szkolnych, organizacji kulturalnych, pośredniczenie pomiędzy lokalną władzą publiczną

\footnotetext{
10 Y.M. Cann, op.cit., s. 2.

11 IFOP, Analyse..., op.cit., s. 15-25.
} 

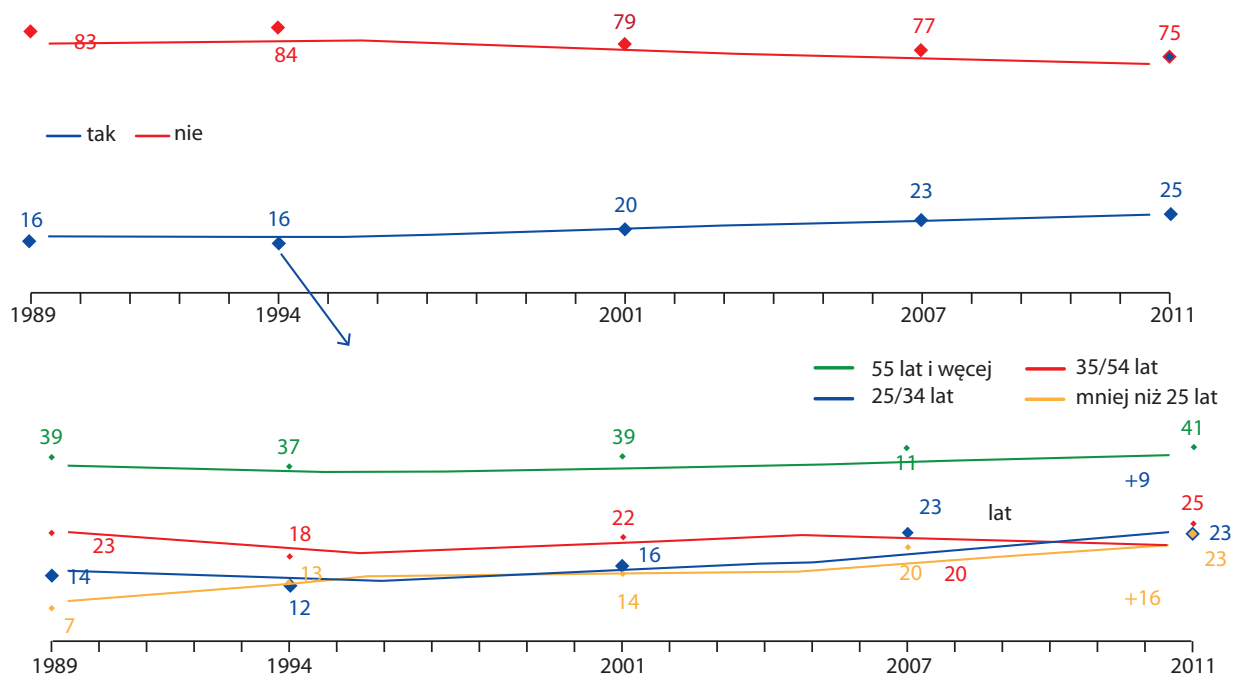

Wykres 4: Uczęszczanie do meczetu w piątki (1989-2011)

Źródło: IFOP, Analyse..., op.cit., s. 9.

a wspólnotami lokalnymi, co przyczynia się do ich integracji na bazie wartości republikańskich ${ }^{12}$.

Integracja muzułmanów na bazie religijno-etnicznej, ale kraju pochodzenia, jest celem działania instytucji religijnych państw, z których wywodzą się francuscy muzułmanie. Cel ten jest dokładnie przeciwny zabiegom asymilacyjnym państwa francuskiego. Pośredniczą w jego osiągnięciu głównie wysyłani przez kraje muzułmańskie imamowie.

\section{Rola imamów}

Następnym istotnym problemem dla funkcjonowania społeczności muzułmańskiej we Francji jest odpowiednia liczba i jakość przewodników duchowych - imamów. Samo pojęcie „imam” jest we Francji bardzo szeroko pojmowane

12 Zob. A. Lamchichi, L'immigration marocaine en France, changements et ruptures, „Confluences Méditerrannée" 1999, Automne, nr 31, s. 161-162, http://www.revues-plurielles.org/_uploads/ pdf/9_31_10.pdf., odczyt z dn. 08.03.2013. 
i obejmuje kilka kategorii duchownych. Są to: „studenci posiadający pewną kulturę islamską, akademicy przybyli z zagranicy, robotnicy na emeryturze, lektorzy Koranu oraz imamowie wysłani przez swoje kraje, młodzi absolwenci instytutów czy też uniwersytetów islamskich"13. Brakuje obecnie wiarygodnych danych co do ich liczby. Według źródeł islamskich w chwili obecnej działa ich we Francji od ok. 1500 do $2000^{14}$, natomiast według obecnego ministra spraw wewnętrznych Manuela Vallsa - $1800^{15}$. Tylko co piąty z nich to Francuz ${ }^{16}$. Sytuację komunikacji $\mathrm{z}$ wiernymi pogarsza fakt, iż tylko co trzeci z imamów mówi po francusku. Ich pochodzenie narodowe przedstawia się następująco:

- 40\% Marokańczycy,

- 24\% Algierczycy,

- 6\% Tunezyjczycy,

- 15\% Turcy,

- 9\% Francuzi,

- $6 \%$ pochodzenia subsaharyjskiego ${ }^{17}$.

Wśród nich są tacy, którzy nieodpłatnie wykonują swą posługę, jak też tacy - jest ich trzecia część - którzy są opłacani przez stowarzyszenia zawiadujące domami modlitw oraz przez wiernych. Jest też grupa imamów otrzymujących wynagrodzenie z krajów ich pochodzenia, czego przykładem mogą być imamowie z Algierii (120), Turcji (150) i Maroka (30) ${ }^{18}$. Wagę związków imamów z krajem pochodzenia podkreśla fakt, iż „ponad połowa z 2000 imamów we Francji - jak twierdzi imam z Drancy, Chaghumi - jest mianowana przez kraje muzułmańskie"19. Trzeba tu podkreślić szczególną więź utrzymywaną przez wła-

13 Ch.A. El Habti (Abou Khalid), La situation des imams en France, http://www.majidepinal.fr/ extern/docs/autres/les-immams-de -france.pdf, odczyt z dn. 8.03.2013.

14 Ibidem; zob. także wywiad z Hassenem Chalgoumim, imamem z Drancy: B. Thiolay, Formons des immams francais, http://www.lexpress.fr/actualite/societe/religion/formons-des-immams-francais_917946.html, odczyt z dn. 10.03.2013.

15 Zob. B. Sauvaget, Des immams du terroir, un vou pieux?, http:/www.liberation.fr/societe/ 2013/05/07/des-immams-du-terroir-un-vœuxpieux_901624, odczyt z dn. 8.04.2013.

16 M. Massaoui, La formation des cadres religieux musulmans en France: défis et perspectives, http:// www.saphirnews.com/La-formation-des-cadres-religieux-musulmans-en-France-defis-et-perspectives_a11323.html, odczyt z dn. 28.03.2013.

17 Ch.A. El Habti, op.cit.

18 Zob wywiad z Hassenem Chalgoumim, op.cit.

19 Zob. wywiad z Ömerem-Farukiem Harmanim, radcą ds. religijnych w Ambasadzie Tureckiej w Paryżu: B. Thiolet, 100 mosqées attendent encore leurs imams, http://www.saphirnews.com/100 -mosquees-attendent-encore-leurs-imams_a10565.html, odczyt z dn. 10.05.2013; zob. także S. Jouaneau, Les Immams en France. Une autorité religieuse sous contrôle, Paris 2013, s. 271-303. 
dze Turcji z mianowanymi przez te władze imamami. Chodzi tu zarówno o więź materialną - są oni opłacani przez państwo tureckie - jak też więź „służbową," gdyż - jak stwierdził w wywiadzie radca ds. religijnych w ambasadzie tureckiej "nie mogą oni mówić, czy też robić, co im się podoba" ${ }^{2}$.

Jedynie imamowie etatowi korzystają $\mathrm{z}$ wszelkich praw finansowych i korzyści ekonomiczno-społecznych, pozostałym trudno utrzymać się z datków wiernych i stowarzyszeń zawiadujących meczetami i zmuszeni są podejmować dodatkowe zajęcia lub też opuścić swą służbę. Ta zależność od źródeł finansowania przekłada się na postawę ideologiczną i polityczną imamów. Wskazuje się także we Francji - nawet w środowiskach islamskich - na ich różny poziom intelektualny: od uczonych do ignorantów nastawionych na zyskowność wykonywanej posługi ${ }^{21}$.

Taki stan rzeczy jest spowodowany w dużej części słabością systemu kształcenia imamów we Francji. Do 1992 roku nie istniała żadna placówka, która zajmowałaby się tym problemem. Dopiero w ramach powołanej przez organizacje islamskie w tymże roku w Château-Chinon w Nièvre niewielkiej prywatnej szkoły pod nazwą Europejski Instytut Nauk Humanistycznych, kształci się - między innymi - imamów. Placówka jest prowadzona przez Unię Francuskich Organizacji Islamskich (UOIF), powiązaną z Braćmi Muzułmańskimi. Stąd też przekazywane w niej treści nauczania - co podkreślają zarówno środowiska islamskie, jak i polityczne - nie odpowiadają republikańskim wartościom państwa francuskiego ${ }^{22}$. Drugim prywatnym ośrodkiem kształcenia imamów jest otwarty w Mantes-la-Jolie w październiku 1993 roku Francuski Uniwersytet Islamski (Université Islamique de France - UIF), przekształcony następnie w Instytut Studiów Islamskich w Paryżu. Trzeci ośrodek, Instytut Teologii Meczetu Paryskiego, powstał w październiku 1994 roku. Inną inicjatywą prywatną był powstały w 2006 roku, dzięki inicjatywie głównego imama przy meczecie w Lille, Instytut Muzułmański imienia Evicenny (Institut Evicenne). Kształci on imamów w języku francuskim. W tym samym roku co instytut w Lille powstało też Centrum Shâtibî w Lyonie. Wszystkie te instytucje powołano dla kształcenia imamów bardziej teoretycznie, niż to jest w praktyce. W rzeczywi-

${ }^{20}$ Ibidem.

${ }^{21}$ Ch.A. El Habti, op.cit.

22 Zob. B. Thiolet, op.cit.; R. Włoch, Polityka integracji muzułmanów we Francji i Wielkiej Brytanii, Warszawa 2011, s. 195. 
stości są one bardziej nakierowane na ogólne kształcenie religijne niż tworzenie kadr islamskich duchownych ${ }^{23}$.

Przeszkodą dla publicznego, uniwersyteckiego kształcenia imamów we Francji jest prawna zasada rozdziału państwa i religii. Zasada ta powoduje, iż państwo laickie nie dysponuje odpowiednimi uprawnieniami w dziedzinie kształcenia nie tylko imamów, ale też wszelkich duchownych religijnych. Stąd też, gdy premier Dominique Villepin przedstawił projekt utworzenia studiów kształcących przyszłych imamów, obejmujący tematykę „Społeczeństwa i cywilizacje współczesnej Francji”, Uniwersytet Paryski odrzucił go jako niezgodny ze wspomnianą zasadą laickości państwa ${ }^{24}$. Z tej patowej sytuacji wyjście znalazł w 2008 roku Wielki Meczet Paryski, który w 2007 roku wspólnie z Instytutem Katolickim w Paryżu uruchomił dwusemestralne studia nakierowane na zapewnienie imamom, zarówno wywodzącym się z Francji, jak też z zagranicy, uniwersyteckiej wiedzy oraz na promowanie umiarkowanej wersji islamu. W lepszej sytuacji pod tym względem są dwa departamenty Alzacji oraz departament Mozeli. Ta ich szczególność polega na obowiązywaniu tam konkordatu podpisanego jeszcze przez Napoleona Bonapartego z papieżem Piusem VII w 1801 roku. Konkordat przestał obowiązywać we Francji po wejściu w życie ustawy z 1905 roku oddzielającej państwo od Kościołów. Jednak zachował swoją ważność we wspomnianych departamentach, które po wojnie francusko-pruskiej z lat 1870-1871 stały się częścią zjednoczonych Niemiec. Po powrocie do Francji w 1918 roku zachowały one regulacje konkordatowe w wyniku presji mieszkańców odzyskanych ziem. Podobnie stało się po II wojnie światowej. Między innymi zachowano przepisy prawne dotyczą kształcenia religijnego ${ }^{25}$, lecz tylko w obszarze uznanych w konkordacie religii: katolickiej, luterańskiej, reformowanej i mojżeszowej. Stąd też możliwe jest kształcenie religijne na poziomie wyższym $w$ instytucjach publicznych, co ma miejsce na

\footnotetext{
23 Zob. M. Massaoui, op.cit.

24 Zob. R. Włoch, op.cit., s. 196.

25 Zachowano prawo mianowania przez państwo arcybiskupów Strasburga i Metzu, przewodniczących i wiceprzewodniczących organizacji protestanckich oraz konsystorza żydowskiego, a także zapewnienie przez władze municypalne funkcjonowania parafii i wspólnot religijnych. W departamentach tych nauczanie religijne w szkołach jest obowiązkowe. Jednak rodzice mogą wystąpić o zwolnienie swych dzieci z tego obowiązku. W rezultacie 75\% dzieci w szkołach podstawowych, 50\% w gimnazjach i tylko $10 \%$ w liceach uczęszcza na religię. Zob. Pourqoi le Concordat s'applique en Alsace - Moselle, http://www.lefigaro.fr/politique/2012/01/26/01002-20120126ARTFIG00484-ourqoile-concordat-s-applique-en-alsace-moselle.php, odczyt z dn. 20.12.2012.
} 
dwóch wydziałach teologicznych (katolickim i protestanckim) Uniwersytetu w Strasburgu oraz w katedrze teologii Uniwersytetu w Metz. Z formalnego punktu widzenia ustalenia konkordatowe nie dotyczą islamu. Jednak bardzo silne $\mathrm{w}$ tych departamentach wspólnoty muzułmańskie, zwłaszcza turecka, czynią starania o powołanie na Uniwersytecie w Strasburgu wydziału teologii islamskiej ${ }^{26}$. Kroki podejmowane w tym kierunku spotykają się z przychylnością władz francuskich, które dążą do „francyzacji” islamu ${ }^{27}$. Staje się to koniecznością, gdyż - jak piszą Jonathan Laurence i Justin Vaïsse - „wielu imamów w dzisiejszej Francji jest językowo i kulturowo odseparowanych od francuskiego środowiska, w którym działają" ${ }^{\prime 28}$. Dodajmy, iż wielu z nich głosi poglądy polityczne nieprzystające do francuskiej racji stanu.

Próby zdiagnozowania religijnych, ideologicznych i politycznych postaw imamów francuskich podjął się Instytut Badań nad Bezpieczeństwem Wewnętrznym (Institut des Hautes Études sur Sécurité Intérieur - IHESI). Przeprowadził on badania między wrześniem 1999 a czerwcem 2001 roku, których przedmiotem była tematyka kazań (chutby) w domach modlitwy. Na podstawie badań29 ich inicjatorzy wyróżnili trzy trendy w tematyce kazań:

- w pierwszym, preferowanym przez starszych imamów, akcent położony jest na ukazywaniu wizji apokaliptycznych, których genezą są grzechy oraz brak bojaźni bożej. Przedstawiciele tego trendu bliscy są „Towarzystwu Misjonarzy" (Dżamảat AT-Tabligh) i porównuje się ich często do Świadków Jehowy;

${ }^{26}$ Zob. wywiad z Ömerem-Farukiem Harmanim, radcą ds. religijnych w Ambasadzie Tureckiej w Paryżu, http://www.saphirnews.com/100-mosquees-attendent-encore-leurs-imams_a10565.html, odczyt z dn. 20.02.2013. Zob. także: S. Sellam, La France et ses musulmans. Un siècle de politique musulmane 1895-2005, Paris 2006, s. 285-290.

27 Jednym z istotnych instrumentów tej polityki są porozumienia między Francją a krajami islamskimi w sprawie organizowanych we Francji dla przyszłych imamów corocznych kursów języka francuskiego i wiedzy prawnej z zakresu obowiązującego we Francji prawa, a szczególnie przepisów związanych z laickością państwa. W czerwcu 2013 roku przyjęto pierwszych 25 kursantów algierskich (według umowy winno być 40). Od 2001 roku Algieria, Maroko i Turcja wysyłają do Francji 40 imamów mających status urzędników państwowych państwa wysyłającego. Zob. I. Mandraud, Á Alger, la France enseigne aux imams le concept de laïcité, http://www.lemonde.fr/afrique/article/2013/06/28/a-algerla-france-enseigne-aux-imams-le-concept-de-laicite_3438597_3212.html, odczyt dn. 28.03.2013.

28 J. Laurence, J. Vaisse, Integrating Islam. Political and Religious Challenges in Contemporary France, Washington 2006, s. 118; cyt. za: R. Włoch, op.cit., s. 194.

${ }^{29}$ Wyniki tych badań zob. M. Widy, Życie codzienne w muzułmańskim Paryżu, Warszawa 2005, s. 59; K. Gajlewicz-Korab, Obraz muzułmanów we Francji w tamtejszych tygodnikach opinii, Warszawa 2011, s. 69. 
- w drugim, spotykanym w kazaniach młodych imamów, zachęca się wiernych do uczestnictwa w życiu społecznym, w wyborach, przypomina się o obowiązkach obywatelskich, nie przeciwstawia się islamu wartościom republikańskim. Tematyka polityczna poruszana jest rzadko;

- w trzecim wyraźne są akcenty tzw. małego dżihadu, czyli walki z niewiernymi w celu przebudowy Francji w państwo muzułmańskie.

Ten ostatni trend co prawda występuje rzadziej niż dwa poprzednie, jednak staje się dużym problemem dla państwa francuskiego, gdyż prowadzi do zaangażowania politycznego części imamów i wiernych po stronie ekstremizmu islamskiego. Z tego powodu wydalono z Francji od września do 2001 do 2011 roku 31 imamów oraz 166 islamistów ${ }^{30}$, zaś wśród więźniów Guantanamo znalazło się 7 naturalizowanych Francuzów ${ }^{31}$.

Ostanie walki w Syrii i Iraku oraz w ich trakcie powstanie Państwa Islamskiego stały się źródłem nowej fali integryzmu islamskiego we Francji. Jej rozmiar spowodował, iż minister sprawiedliwości Christiane Taubira powołała w październiku 2014 roku tzw. programy deindoktrynacji walczące $\mathrm{z}$ dżihadystycznymi tendencjami młodzieży francuskiej. Pomocna w tym jest powstałe w tym celu Centrum Prewencji przeciw Wypaczeniom Sektowym Związanym z Islamem (Centre de prévention contre les dérives sectaires liées à l'Islam - CPDSI). Konieczność takich działań staje się pilna nie tylko wśród środowisku islamskim, ale i wśród rdzennych Francuzów z uwagi na fakt, iż corocznie od 2010 roku zwiększa się o 20\% liczba ich konwersji na islam ${ }^{32}$. Jednak w tym przypadku mniejszą rolę odgrywają imamowie lokalni, ustępując pola internetowi ${ }^{33}$. To właśnie głównie poprzez internet następuje rekrutacja francuskich bojowników Państwa Islamskiego ${ }^{34}$.

30 Zob. F. Béguin, Comment se décide l'expulsion d'imams radicaux?, http://www.lemonde.fr/societe/article/2012/11/01/comment-se-decide-l-expulsion-d-imams-radicaux_1784307_3224.html, odczyt z dn. 21.03.2013.

31 Zob. A. Conchiglia, Des Français oubliés à Guantanamo, http://www.monde-diplomatique. fr/2004/04/CONCHIGLIA/11129, odczyt dn. 10.10.2012.

32 Zob. Conversion à l'Islam: „Les jeunes français souffrent d'un malaise identitaires”, http://www. lefigaro.fr/vox/societe/2014/11/17/31003-20141117ARTFIG00173-djihad-l-inquietante-radicalisation-des-convertis-francais.php, odczyt z dn. 20.11.2014.

33 Według raportu CPDSI z listopada 2014 roku 91\% francuskich dżihadystów rekrutowanych było poprzez internet. Zob. D. Bouzar, Ch. Caupenne, S. Valsan, La métamorphose operée chez le jeune par les nouveaux discours terroristes. Recherche-action sur la mutation du processus d'endoctrinement et d'embrigadement dans l'islam radical, novembre 2014, http://www.bouzar-expertises.fr/metamorphose, odczyt z dn. 22.11.2014, s. 13-14.

34 Według danych oficjalnych 1100 Francuzów są członkami ugrupowań dżihadowskich, w tym $380 \mathrm{z}$ nich przebywa aktualnie w Syrii i Iraku, a 50 znalazło tam śmierć. Zob. Trois djihadistes français 


\section{ORGANIZACJE MUZUŁMAŃSKIE WE FRANCJI}

Właściwie dopiero od początku lat osiemdziesiątych XX wieku możemy mówić o pojawieniu się we Francji muzułmanów jako organizującej się społeczności religijnej, a nie tylko zjawiska ograniczonego do wymiaru jednostkowego i rodzinnego. Złożyły się na to takie przyczyny, jak: nowa fala migrantów w drugiej połowie lat siedemdziesiątych przybyłych w ramach łączenia rodzin, związane z tym stabilizowanie się sytuacji rodzinnej imigrantów i ich „zakotwiczenie we Francji”, finansowe wsparcie francuskich muzułmanów przez kraje ich pochodzenia, początkowo głównie przez państwa Zatoki Perskiej. Jednak główną przyczyną było zniesienie w 1981 roku, po dojściu do władzy socjalistów, ograniczeń administracyjnych, nałożonych jeszcze w 1901 roku i uniemożliwiających obcokrajowcom tworzenia stowarzyszeń. W wyniku tego od początku lat osiemdziesiątych XX wieku francuska społeczność muzułmańska zdynamizowała proces samoorganizowania się.

Charakterystyczną cechą tego procesu do początku XX wieku była jego żywiołowość, co wpłynęło na wielość i różnorodność powstałych stowarzyszeń. Na żywiołowość tę nakładają się jeszcze: podziały etniczne wśród imigrantów, ważące bardziej niż wspólnota religijna (szczególną rolę w tym odegrała rywalizacja algiersko-marokańska), wielość nurtów religijnych, stosunek do zachodniego modelu społeczno-politycznego, różnice pokoleniowe, miejsce osiedlenia czy też wpływ krajów wychódzctwa imigrantów ${ }^{35}$. Nie był on ani sterowany przez nadrzędną władzę tej mniejszości religijnej, bo takiej nie było i w gruncie rzeczy do tej pory nie ma, ani nie był inspirowany przez rząd francuski, który dopiero w drugiej połowie lat dziewięćdziesiątych XX wieku podjął próby wyłaniania partnera do rozmów ze strony społeczności muzułmańskiej. Decydującą rolę odegrali w tym ministrowie spraw wewnętrznych tamtego okresu, Jean-Pierre Chevènement, Daniel Vaillant, a szczególnie Nicolas Sarkozy w czasie swego

brûlent leur passport, http://www.lefigaro.fr/flash-actu/2014/11/19/97001-20141119FILWWW00433trois-djihadistes-francais-brulent-leur-passeport.php, odczyt $\mathrm{z}$ dn. 22.11.2014. Nieco inne dane podaje David Thomson, a mianowicie: 700 dżihadystów francuskich miałoby przebywać w Syrii, $250 \mathrm{z}$ nich uczestniczyć w walkach, zaś 3 wykonało atak samobójczy. Zob. D. Thomson, Les Français jihadistes, Paris 2014, s. 256.

35 Zob. F. Frégosi, La représentation institutionnelle de l'islam en France, [w:] Histoire de l'islam et des musulmans en France du Moyen Âge à nos jours, red. M. Arkoun, Paris 2006, s. 837-855. Muzułmańskie kraje emigracji utrzymują specjalne urzędy ds. wychodźstwa kontrolujące skupiska migracji swych obywateli, na przykład marokańskie ministerstwo MRE (Marocains résident à l'étranger), tureckie Ministerstwo ds. Religijnych, czy też jego odpowiedniki w innych krajach muzułmańskich. 
ministrowania po 2002 roku. Jego wysiłki doprowadziły do powstania w 2003 roku namiastki reprezentacji muzułmańskiej w postaci Francuskiej Rady Kultu Muzułmańskiego (Le Conseil Français du Culte Musulman - CFCM) ${ }^{36}$. Jednak trzeba tu wspomnieć o dużej roli przy jej tworzeniu przedstawicieli państw muzułmańskich, którzy wpływali na jej przebieg przez deklaracje finansowania tego przedsięwzięcia..

Organizacja ta jest oficjalnym reprezentantem muzułmanów przed rządem francuskim. Jej podstawowym składnikiem jest Zgromadzenie Muzułmanów Francuskich (Rassemblement des Musulmans de France), będące pod przemożnym wpływem władz marokańskich. Ich obszar działania to troska o budowę meczetów, rozwój szkolnictwa muzułmańskiego, zachowywania wymogów dla produktów halal, dbanie o muzułmańską posługę religijną we więzieniach i armii.

Inna organizacja powstała na fali wcześniejsze integrowania się lokalnych organizacji muzułmańskich to Unia Francuskich Organizacji Islamskich (L’Union des Organisations Islamiques de France - UOIF). Jest ona jednocześnie członkiem Federacji Islamskich w Europie (Fédération des Organisations Islamiques en Europe - FOIE). Powstała w 1983 roku, powiązana jest z ruchem Bractwa Muzułmańskiego. Stąd też nie dziwi jej ortodoksja religijna i finansowanie jej przez fundusze religijne stowarzyszeń regionu Zatoki Perskiej i inne kraje arabskie. Tworzy ją ok. 200 stowarzyszeń. Jeśli chodzi o praktyczna działalność edukacyjną, to sprawuje ona opiekę nad Europejskim Instytutem Nauk Humanistycznych, kształcącym imamów i nauczycieli religii.

Podobnie zlepkiem organizacji lokalnych jest Narodowa Federacja Muzułmanów Francuskich (Fédération Nationale des Musulmans de France - FNMF). Założona została w 1985 roku z inicjatywy muzułmanów marokańskich, których delegaci stanowią obecnie większość w CFCM. Jej profil ideologiczny jest wyraźnie konserwatywny, przeciwstawny tendencjom postępowym w islamie. Występuje przeciwko jego polityzacji, a szczególnie przeciw terroryzmowi.

Wśród francuskich organizacji muzułmańskich wyróżnia się przez swój fundamentalizm, jednak bez akcentów politycznych, Tabligh, Wiara i Praktyka (Tabligh, Foi et Pratique). Stowarzyszenie to ma wyraźne afiliacje pakistańskie

36 Stowarzyszenie zostało założone 28 maja 2003 roku przez publikację w Journal officiel de la République française le 7 juin 2003. Szeroką panoramę poglądów na temat jego powstania i funkcjonowania zob. Le conseil Français du Culte Musulman: une solution ou un problème?, [w:] L'islam en France, red. Y.Ch. Zarka, S. Taussig, S. Fleury, Paris 2004, s. 63-157. 
i hinduskie, propagując „prawdziwy islam”. Często porównuje się go do Świadków Jehowy przez swój prozelityzm i działalność „od podstaw”, szczególnie w skupiskach muzułmańskich na przedmieściach wielkomiejskich.

Paletę stowarzyszeń muzułmańskich uzupełnia organizacja o zasięgu regionalnym - Francuska Federacja Stowarzyszeń islamskich Afryki, Komorów i Antyli (La Fédération Franşaise des Associations Islamiques d'Afrique, des Comores et des Antilles - FFAIACA). Stowarzyszenie to, powstałe w 1989 roku, skupia głównie młodych muzułmanów Afryki Subsaharyjskiej, głosząc islam postępowy, bliski ideom republikańskim państwa francuskiego ${ }^{37}$.

Osobną rolę wśród francuskich instytucji muzułmańskich odgrywa Wielki Meczet Paryski (La Grande Mosquée de Paris). Meczet ten był pierwszym we Francji metropolitarnej. Oddany został w atmosferze sporów algiersko-marokańskich w 1926 roku. Obecnie spełnia rolę - nie przez wszystkie muzułmańskie stowarzyszenia uznaną - naczelnego Meczetu francuskiego. Jego działalność związana jest ściśle z Muzułmańskim Instytutem meczetu Paryskiego (L'Institut Musulman de la Mosquée de Paris - JMMP) oraz z Federacją Wielkiego Meczetu Paryskiego (Fédération de la Grande Mosqée de Paris - GMP). Instytucje te finansowane są ze składek członkowskich oraz przez instytucje algierskie, co ma - oczywiście - wpływ na ich polityczne oblicze i reakcje innych środowisk, zwłaszcza marokańskich i tureckich. Ugrupowania te odegrały decydującą rolę przy tworzeniu Francuskiej Rady Kultu Muzułmańskiego.

37 Zob. F. Frégosi, Quelle organisation de l'islam dans la République?: institutionalisation et/ou instrumentalisation?, [w:] L'islam..., red. Y.Ch. Zarka [et al.], op.cit., s. 96-97. 